\title{
UNLOCKING THE SECRETS OF GOLD ANTIQUITIES
}

\author{
Andrew Oddy \\ Department of Conservation, The British Museum, London WC1B 3DG
}

\begin{abstract}
Modern analytical methods perfected during the past twenty years, including emission spectroscopy, X-ray fluorescence, neutron activation and other nuclear techniques, have made a vital contribution to the study of gold antiquities. As a result of the pioneering work of recent years, most publications of new finds of gold coins or jewellery now include analytical data.
\end{abstract}

As Gold Bulletin enters its 21 st year it is an appropriate moment to look back at the achievements in the scientific study of gold antiquities over the past two decades. This has, in fact, been a momentous period for two reasons. First, curators have become more open towards the idea of taking samples for examination from their most precious objects, and second, the scientific techniques of nondestructive examination have developed significantly during recent years.

The origins of the scientific study of antiquities lies in the early 19th century, when it was mainly ancient coins which were analysed from. Later in that century the specific gravity technique was applied to analyse gold coins, and the complete non-destructiveness of the method meant that quite large numbers of coins could be studied. But specific gravity cannot conveniently be used on larger objects, or those made by casting, or set with precious stones, and so, apart from coins, very little became known about the composition of gold objects of antiquity until relatively recent times.

The first real breakthrough came in the early 1960 s with the development at Oxford of the Milliprobe, an X-ray fluorescence apparatus which focussed the excitation beam onto a very small area of the object to be analysed [1], It thus became possible to obtain analyses of objects without removing a sample and after cleaning only a very small area of the surface, at which the beam of X-rays was pointed. This enabled the Oxford team to carry out a series of studies of early medieval gold jewellery and coins which paved the way for workers in other countries $[2,3$, 4]. What was found was that in the 7 th century there took place a gradual debasement of the gold coinages of Western Europe arising from a gold famine, which is usually attributed to the disruption of trade caused by the Barbarian invasions of Europe from the North and the spread of Islam in the countries to the South bordering the Mediterranean.

The first tangible use of this debasement resulted in a firm date for the famous Anglo-Saxon ship burial found at Sutton Hoo in Suffolk in 1939. It was obvious, from the richness of the treasure in the tomb, that it must have been the grave of one of the seventh century Kings of East Anglia - but which one? The grave contained no named objects, such as a signet ring, apart from a large silver dish marked with the control stamp of the Byzantine emperor Anastasius, who had died at least a century earlier than the burial, and two silver spoons engraved with the names Saul and Paul respectively [5]. These, and other objects in the grave, indicated that the king must have been ruling during the period of the conversion of the East Angles to Christianity. However, they give no idea which of several possible Kings might have been buried inside his ship in the large mound. A clue, however, lay in the purse of 37 Merovingian coins, minted in France in the 6th and early 7th centuries. If the latest of these could be dated, then the approximate date of the burial could be guessed.

Debasement was, of course, the clue to the dating, because if debasement is progressive then the coin containing the least gold must be the latest. Analysis by specific gravity rapidly identified the latest coin, but the question then arises - when was it struck?

At this time in France many towns struck their own 

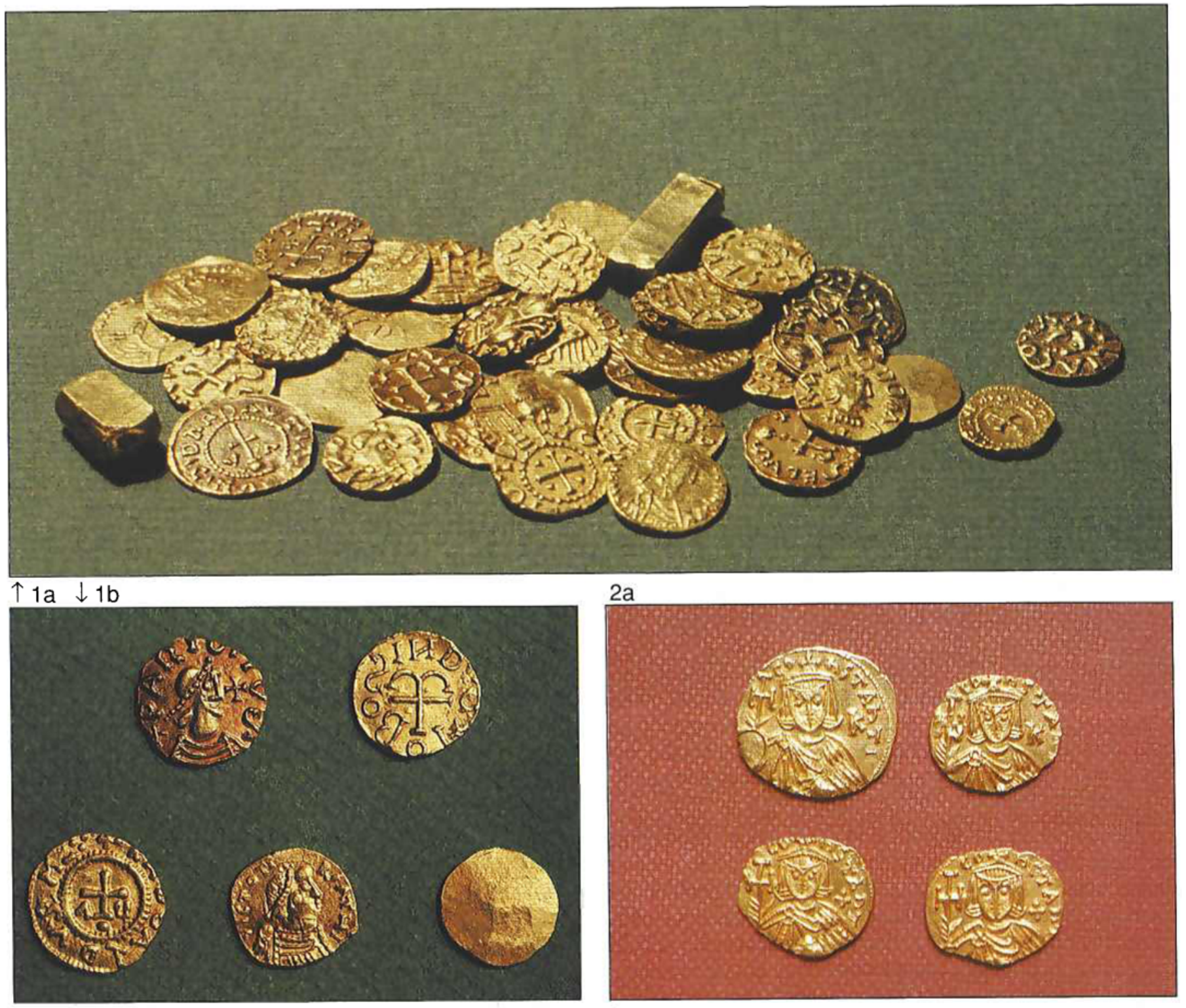

$2 b$

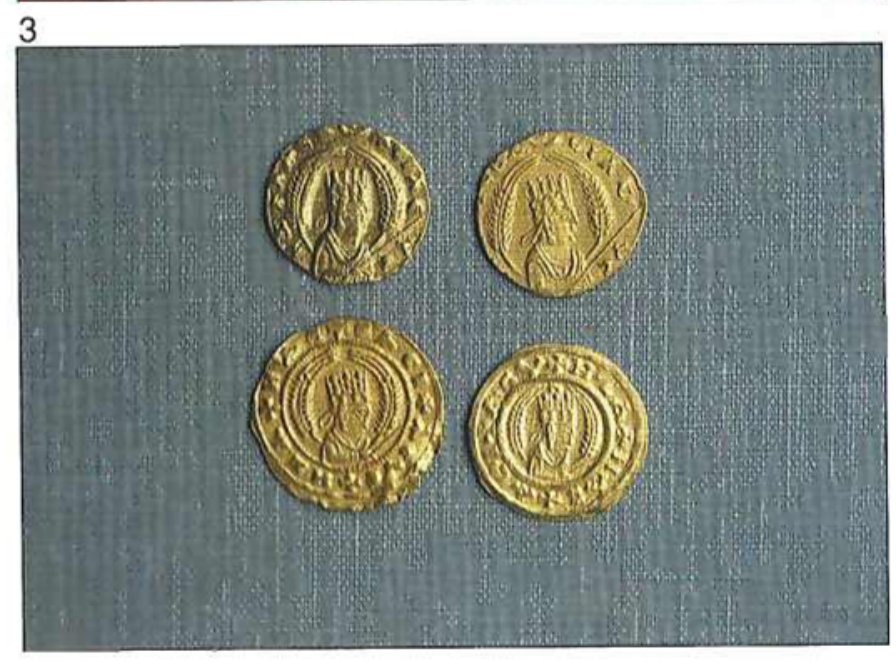


Figs. 1a and 1b Gold coins minted in France in the 6th and 7 th centuries AD and found in the Sutton Hoo Anglo-Saxon ship burial. Analysis of the composition of the coins provided the key to dating the burial

Fig. 2a Coins of the Byzantine emperoros Leo $\mathrm{V}$ and Constantine (AD 813. 820) minted in Sicily in an alloy consisting of 4 parts of gold to 1 part of base metal (mostly silver)

Fig. 2b Coins of Leo III and Constantine V (AD 720-741) minted in Rome. During this reign the debasement of the 'gold' coinage became complete. The compositions of the coins shown here are: top left- $\mathbf{4 5 \%}$; top right$38 \%$; bottom left: silver; bottom right: base silver

Fig. 3 Coins of the Aksumite King Ezanas who was ruling in Ethiopia at the time of the conversion to Christianity towards the middle of the 4th century AD. The upper two coins belong to the pagan period of the reign and the lower two to the Christian period

coins without putting the name of the king on them and so it is impossible to date them at all closely on stylistic grounds. However the Kings did also issue their own coinage and by analysis of a large number of these Royal coins it was possible to draw a time vs. fineness graph for the 7 th century Merovingian royal coinage $[6,7]$. If it can be assumed that the non-royal (i.e. municipal) issues were struck to the same gold standard as the contemporary royal coinage, then it should be possible to date the 'town' issues from the 'royal' debasement graph. In fact, it was possible to show by this approach that the latest coin in the Sutton Hoo grave must have been struck in about AD 625, which fits exactly with the date of death of Redwald, the greatest of the Kings of East Anglia, and overlord for a time of the whole of Southern England [8].

All the analyses used for the work on the Merovingian coinage were carried out by an improved specific gravity technique in which the immersion liquid was a fluorocarbon with a density nearly twice that of water $[9,10,11]$. But at the same time, developments of neutron activation analysis led to the use of this technique for the nondestructive analysis of gold coins [12] In fact, this is the only other completely non-destructive technique apart from specific gravity, and, like the latter, it samples the whole coin because the whole coin is irradiated, thus eliminating errors due to corrosion effects in the alloy near the surface.

In more recent years a French team have applied nuclear methods of analysis on a grand scale to the study of Roman and Byzantine coins, contributing significantly to our knowledge of monetary and economic history [13]. Their first results have enabled them to quantify the debasement of the Roman gold coinage, first in the later third century and then again in the fourth. Corresponding with the second of these debasements, in the middle of the fourth century, a sharp rise in the platinum content of the gold was detected, and attributed in part to the exploitation of new sources of gold.

For the subsequent Byzantine period, debasement in the eleventh, and again in the thirteenth centuries has long been known [14], as it is obvious from the appearance of the coins themselves, but modern analyses, building on older specific gravity data, has now clarified the picture. As the debasement consists of admixtures of both silver and copper, specific gravity could never give a clear picture of the process, but it still contributes to debasement studies where the only element being added to the gold is silver. Hence the debasement of the later Byzantine coinage of Italy and Sicily was first explained and closely dated by this technique in 1975 [15], although more modern methods have amplified the picture since then [16].

An even more spectacular use of debasement studies has been to suggest a chronology for the Kings of Aksum, the old name for Ethiopia, who ruled during the first millennium AD [17]. Very few historical sources survive for Africa south of the Sahara until relatively modern times, but the existing architectural remains in Ethiopia, and the coinage, show that the Aksumite kingdom was a flourishing one, probably as a result of the trade in slaves and ivory via ports on the Red Sea. Although more than twenty Kings' names appear on coins, only two of them (Ezanas and Khaleb) can be approximately dated, in both cases as a result of their contacts with the Roman or Byzantine empires [18]. Now, however, analysis of the gold coins has shown that there is a debasement and so the Kings have been arranged in descending order of coin purity [19]. In fact, this order also agrees with the rather meagre archaeological and epigraphic evidence which is also avail-

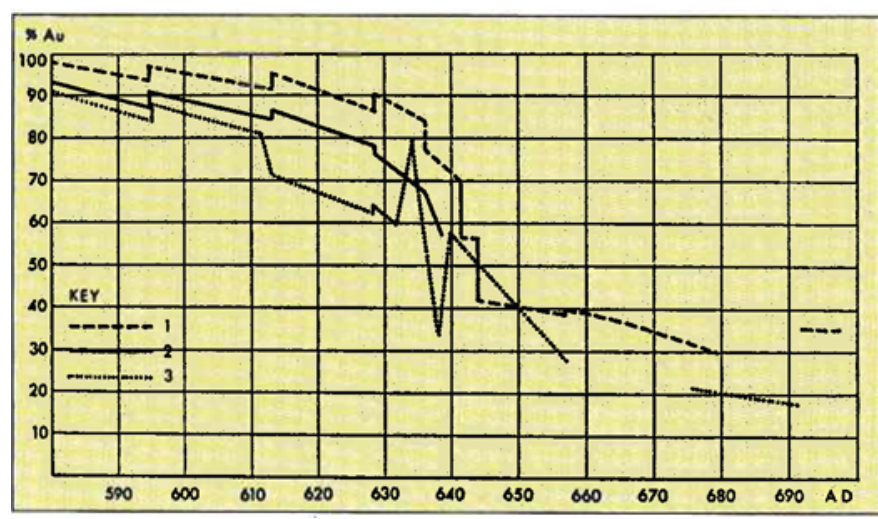

Fig. 4 Time vs. fineness graph for gold coins minted in France in the 6th and 7 th centuries $\mathrm{AD}$. The analysis of coins of known date provided the data for the graph, which was then used to estimate the dates of coins from Sutton Hoo ship burial by first measuring their gold content 


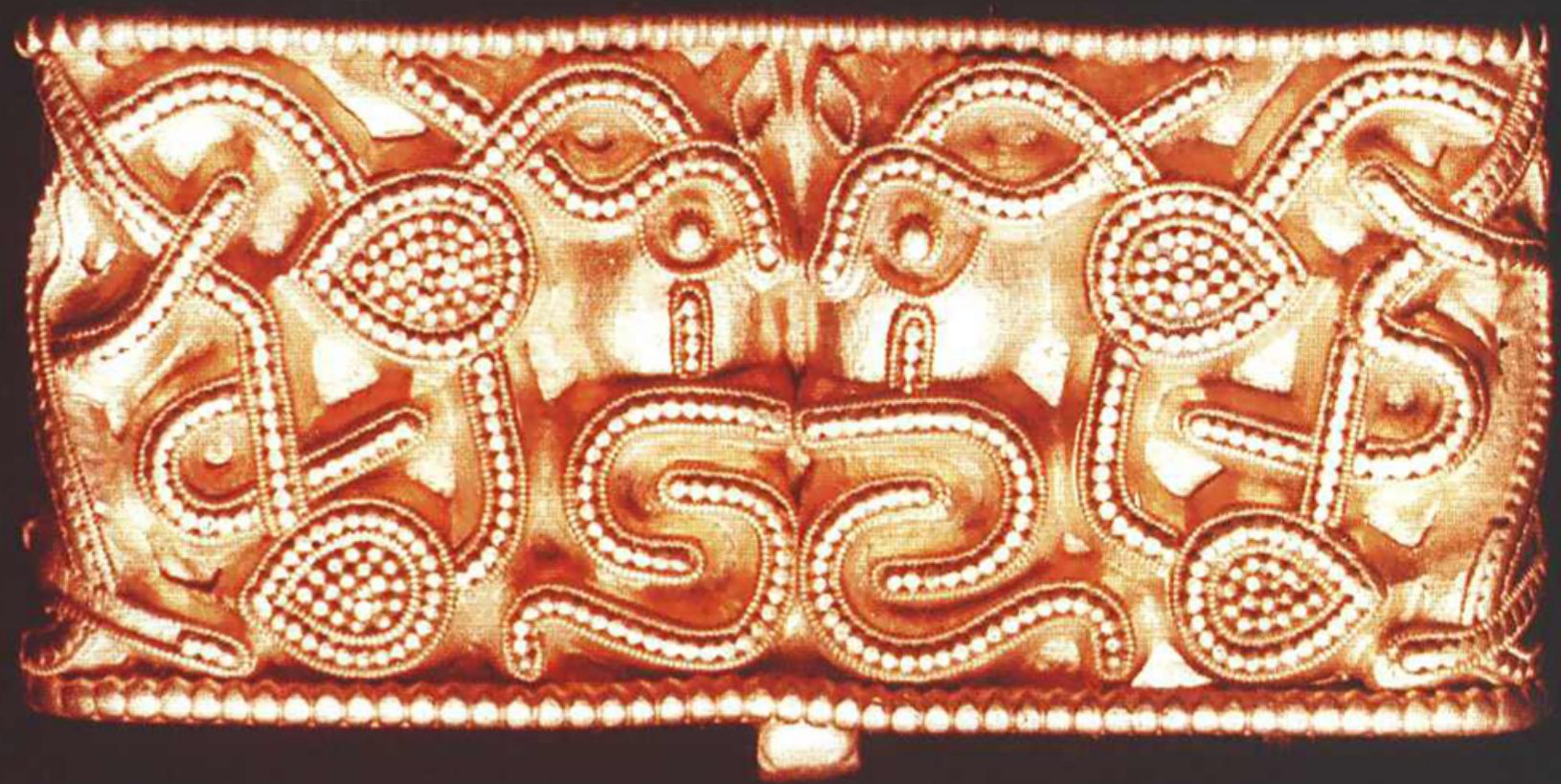

$\uparrow 5 \downarrow 6$

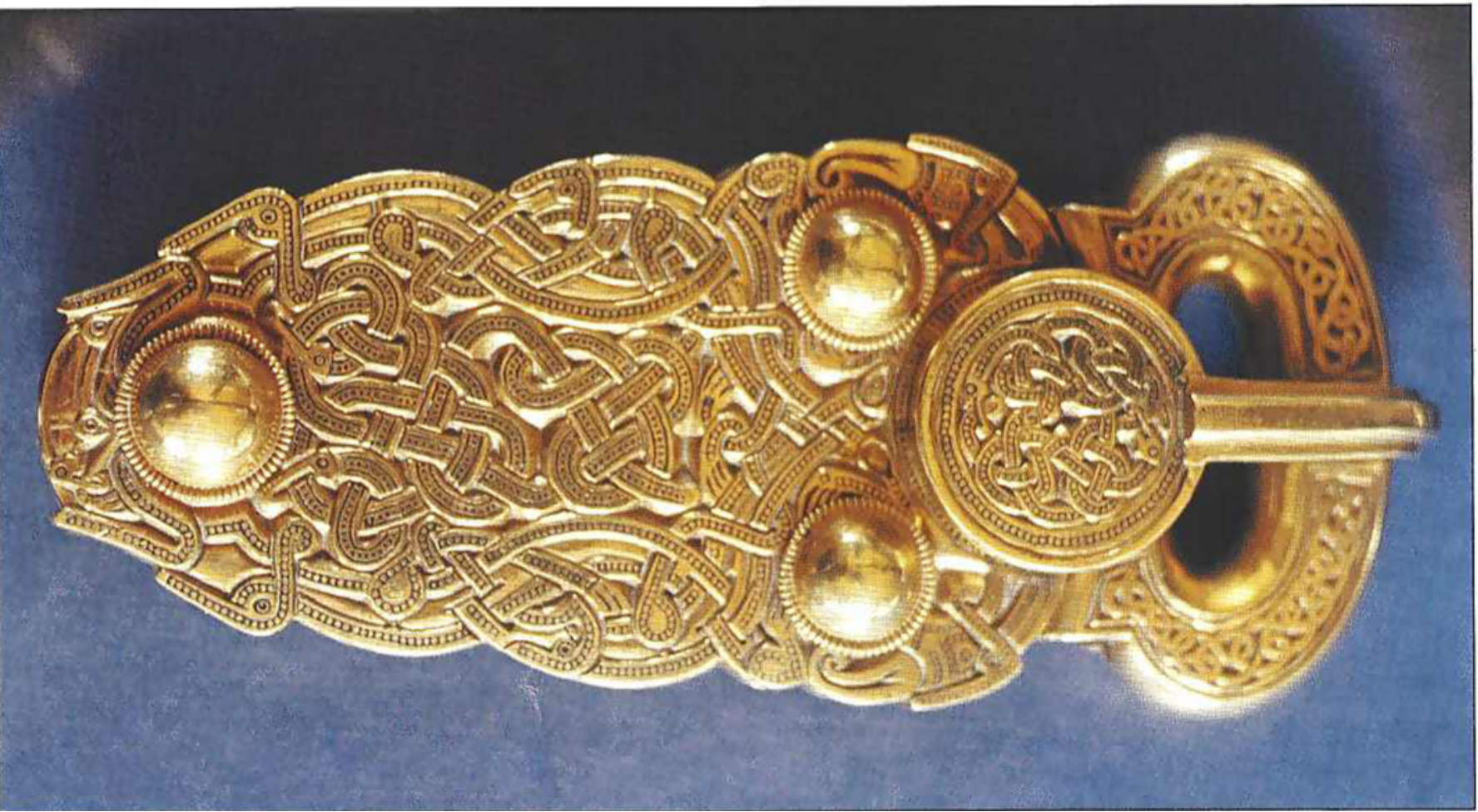


Fig. 5 Gold scabbard mount of the 6th century AD from Sodermanland, Sweden. Analysis has shown that it contains $90 \%$ of gold

Fig. 6 The great gold buckle from the Sutton Hoo ship burial. Analysis has shown that the various components contain between 80 and $90 \%$ of gold

Fig. 7 Part of the Late Roman treasure found at Gallows Hill, Thetford, U.K., in 1979. The gold contents of the jewellery varied between 89 and $98 \%$. The alloying elements were silver and copper

able, and has won the general agreement of historians.

The study of coins has provided a natural source of analytical material since the development of modern nondestructive methods, but museum scientists have by no means confined their activities to coins. Gold jewellery has also featured in various analytical programmes, in particular that of Migration Period Sweden. However, attempts to correlate the gold content with the supposed date of the artifacts has not been particularly successful [20]. Besides the work on Swedish finds, the publication of the treasure from Sutton Hoo was the inspiration for an analytical study by $\mathrm{x}$-ray fluorescence of this and of some of the other surviving Anglo-Saxon gold jewellery. This showed that the alloys contain copper as well as silver, but that copper was usually well below $5 \%$. The gold contents ranged from about $50-95 \%$, but again the composition only correlated very approximately with the date assigned on stylistic grounds [21]. It is clear, however, that the gold famine which affected the Merovingian coinage in the seventh century was reflected in the increasing scarcity of gold available for making jewellery in Western Europe.

In the Byzantine and Islamic Empires at the eastern end of the Mediterranean, however, gold was not in short supply and the coinage and jewellery of the later first millennium AD remained fairly pure. Several studies of the various Islamic coinages by specific gravity analysis have shown consistently high purity of the gold [22], usually better than $95 \%$, but, unfortunately, no analyses have yet been carried out on the related jewellery. Some data is available for Byzantine jewellery, which relates it, in general terms, to the contemporary coinage [23].

Apart from the study of alloy composition, museum scientists have also found it interesting to look at platinum group metal inclusions (usually osmium, iridium and/or ruthenium) which are visible on the surface of artifacts

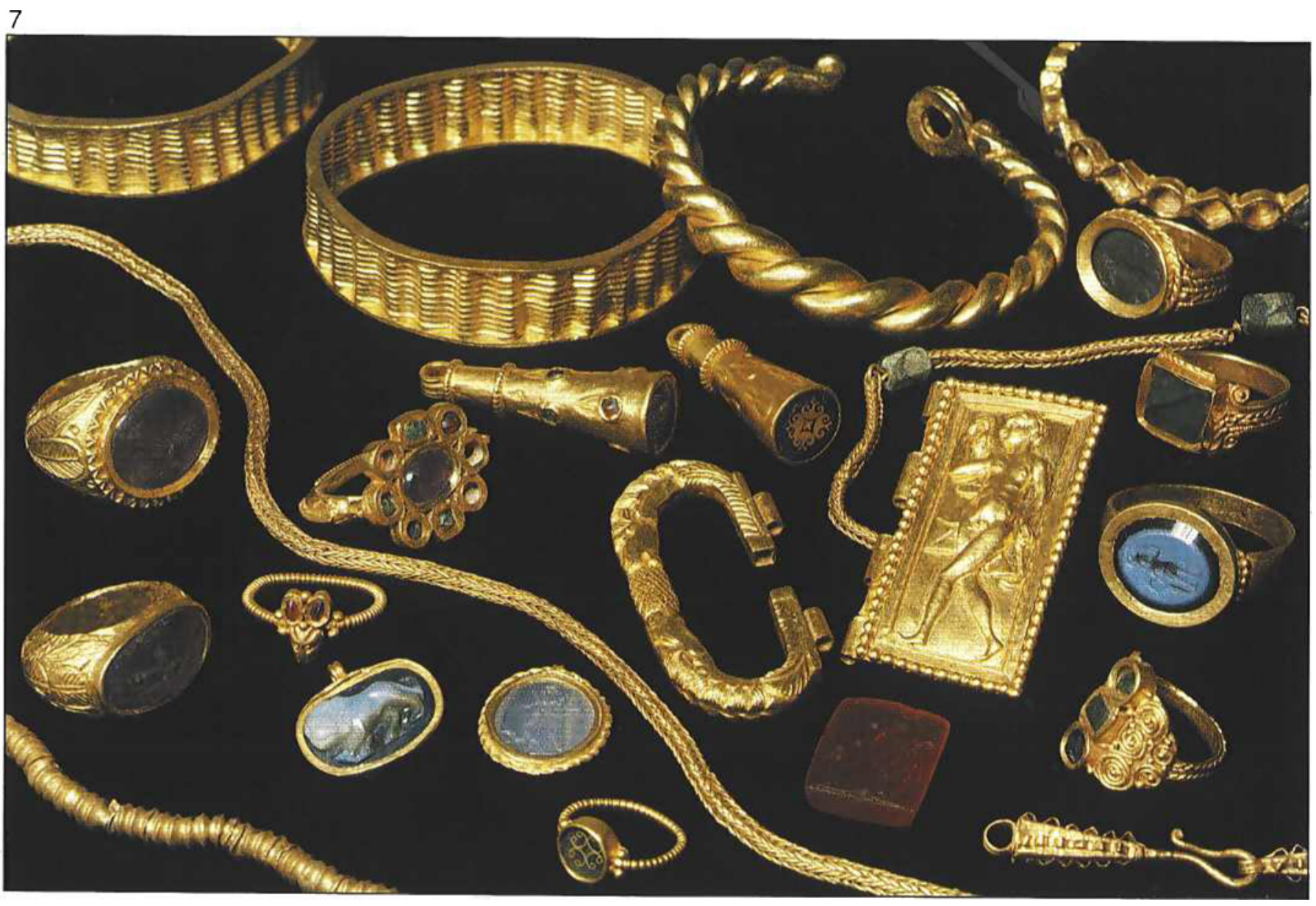

Gold Bull.. 1988, 21(1) 


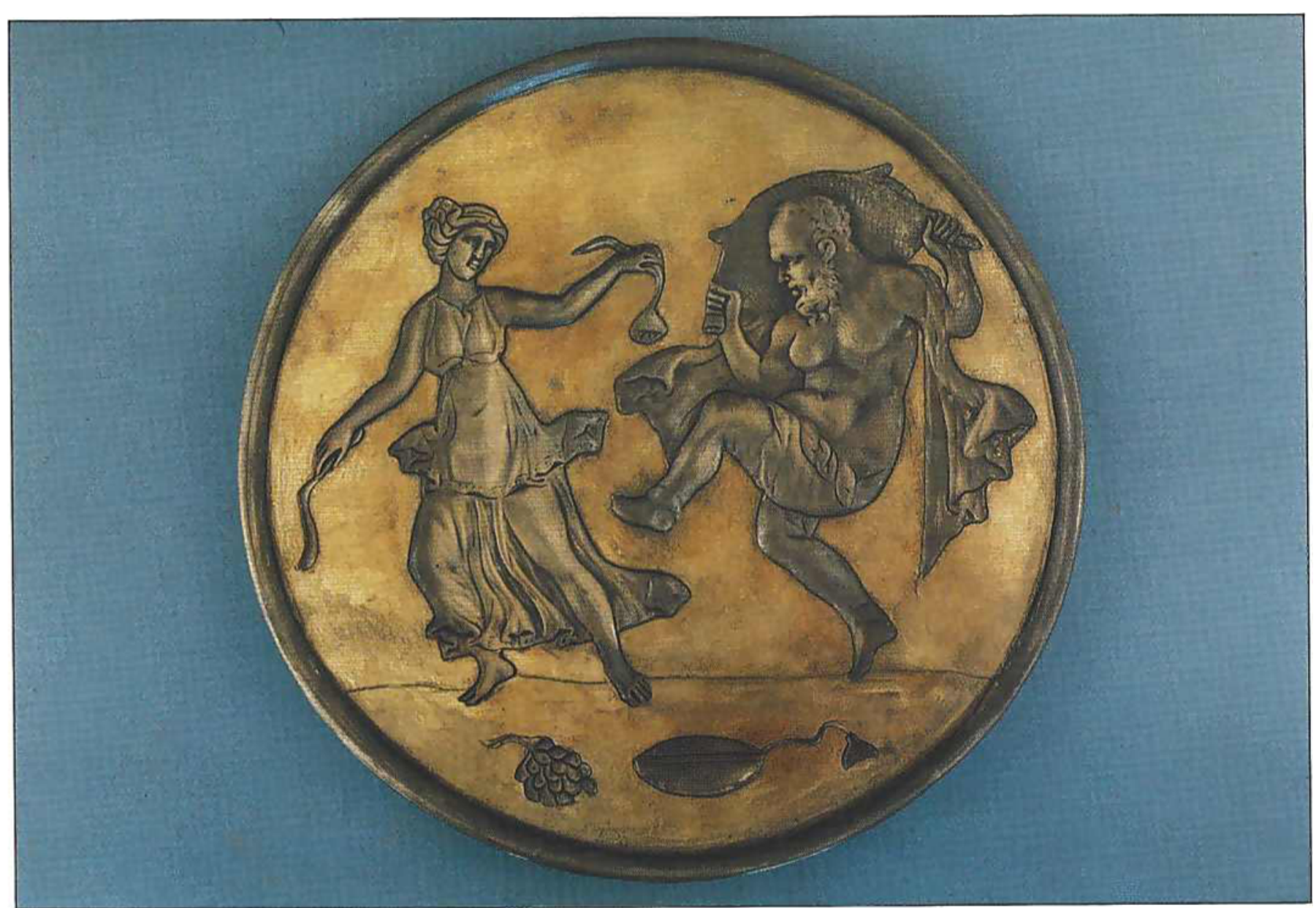

Fig. 8 Byzantine silver dish made in the reign of the Emperor Heraclius (AD 610-641) and found in 1878 in the village of Kalganovka, near Solikamsk, in the Soviet Union. The upper surface of the dish was gilded by the 'fire-gilding' process

$[24,25]$. It was hoped that their presence or absence might be an indication of provenance, but in spite of careful study this goal has not been achieved. The presence of these inclusions is, however, a useful guide to authenticity, as the platinum group metals are always removed from recently mined gold by the modern methods of refining.

Most of the work described so far has been concerned with objects made during the first millennium AD, but prehistory has not been neglected by the analysts. One of the most thorough analytical surveys had been that carried out by Hartmann on prehistoric gold jewellery and related items [26, 27]. Hartmann analysed several hundred objects from museums all over Europe by emission spectroscopy, and published a data-base which has become a fundamental tool for those who have followed. Now the corpus of analyses is growing bit by bit as new finds are published.

In fact, as a result of the pioneering work of recent years, it is now regarded as usual for the publication of major catalogues of gold coins or jewellery [28], or of new finds, to include analytical data which, on its own, means very little, but taken in the wider context of a growing body of results is gradually painting a picture of the technology of times gone by.

Besides the investigation of the composition of gold objects in the past, other aspects of their technology are also beginning to receive attention. The setting of precious stones in soft backing pastes in early medieval jewellery is just one aspect which has recently been studied, along with techniques of gem-cutting and mounting [29]. Other scholars have carried out similar investigations of jewellery from the Classical world and its forerunners [30]. Individual studies have involved the making of wire, where the investigation of gold jewellery is particularly important as the non-corroded state of the surface preserves the evidence of how the wire was made [31].

Apart from making objects of gold itself, man has used it to cover artifacts made of baser metal since at least 3000 BC. The methods used to gild objects of silver and copper (or bronze) have been widely studied in recent years [32, 
33]. The earliest method was to wrap gold foil round an object, but subsequently, when man had learnt how to hammer the gold even thinner, gold leaf was stuck to the surface either with an adhesive, or by heating and burnishing to cause interdiffusion of the gold and the substrate metal to take place. In China in about the fourth century BC, however, a new discovery took place which was to revolutionise gilding for more than 2000 years. The Chinese discovered that if a gold amalgam was spread on the cleaned surface of a silver or copper object which was then heated, the mercury evaporated and the gold formed a very strongly bonded layer on the surface. Large numbers of surviving gilded objects in museums attest to the efficiency of this gilding process, which continued in use throughout the Middle Ages and later periods until rendered obsolete by the invention of electroplating in the middle of the nineteenth century [34].

This survey has concentrated on the contribution of science, and particularly of analytical chemistry, to our knowledge of the technology of gold in Europe and the Old World and it has rather ignored the fascinating civilization of pre-Columbian America. In recent years, however, considerable metallurgical research has been carried out on artifacts made of gold alloys, although here the alloy was often one of gold and copper [35]. One particular area of interest is again the technology of gilding, and the existence of very thin gold layers which were not applied with the aid of a gold amalgam has prompted one scholar to propose an electrochemical process to explain her findings [36]. Apart from the deposition of gold on the surface, the South American civilizations were well known for making gold/copper objects and then pickling them in fruit acids to dissolve the copper out of the surface layers and so produce a gilded effect. This process is known as depletion gilding.

With its policy of usually including a historical article in most issues, Gold Bulletin has played a very important role during the last 20 years in bringing the advances in the scientific study of antiquities to the notice of a wider audience. Some of the more important analytical papers have been referred to already, but in addition there have been a number of historical papers written with a technological slant within the pages of this journal. For example, 'Gold Technology in Ancient Egypt' (vol. 5), 'Gold Brazing in Antiquity' (vol. 6), 'Ancient Egyptian Gold Refining' (vol. 7), 'Gold Working Practice at Pompeii and the Gilding of Armour' (vol. 10), 'Gold in Ancient Palestine' (vol. 12), 'The Long History of Lost Wax Casting' (vol. 13), 'The Ancient Craft of Granulation' (vol. 14), 'Enamelling on Gold and Gold in Antique Copper Alloys' (vol. 15), 'Assaying in Antiquity and Japanese Shakudo' (vol. 16), 'Analysis of Gold Jewellery Artifacts

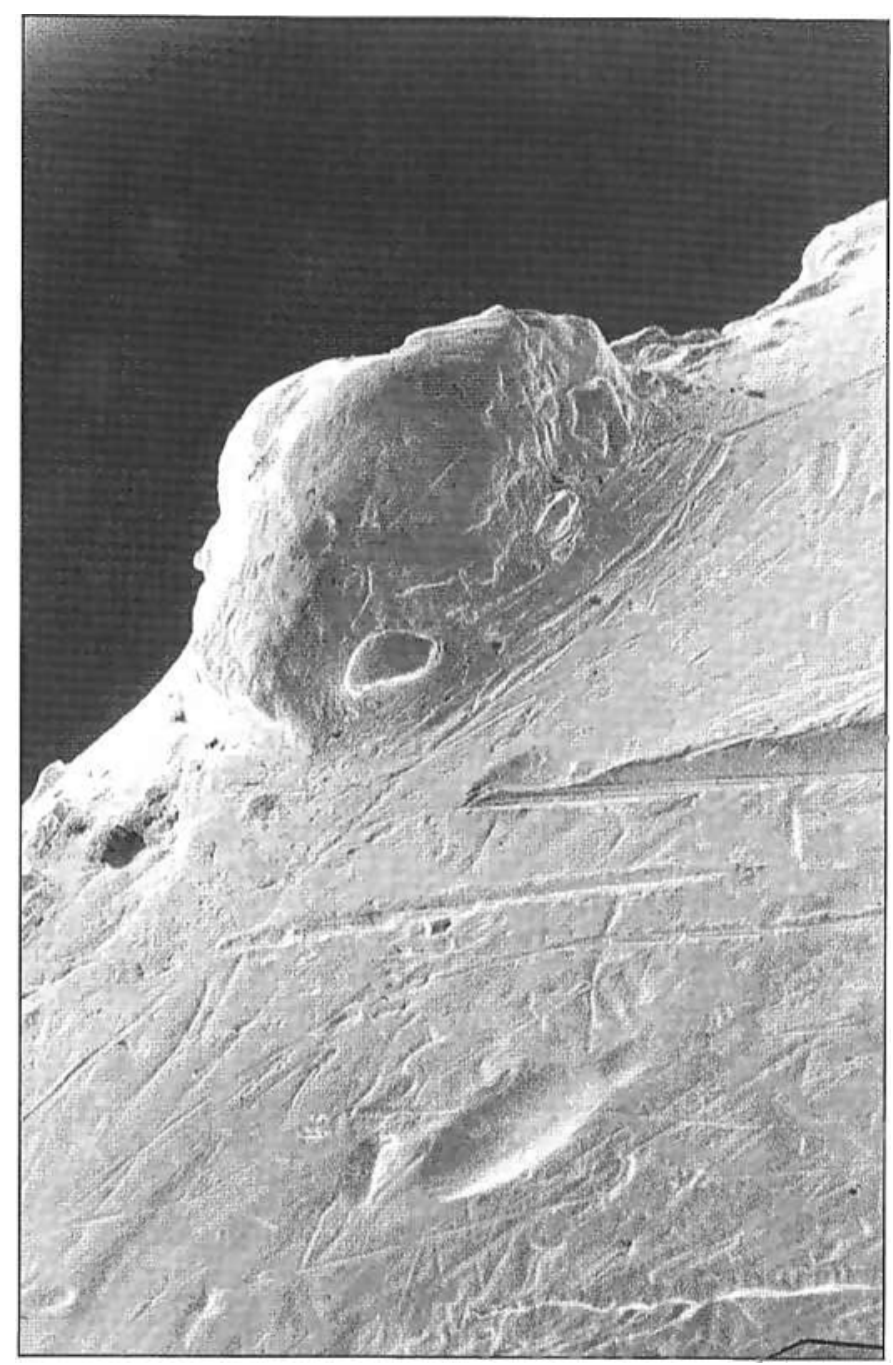

Fig. 9 Scanning electron micrograph of an osmium/irridium/ruthenium inclusion standing proud of the surface of a gold earring of the Roman period

(Scale: $1 \mathrm{~cm}=7 \mathrm{rm}$ )

and Gold in the Southern African Iron Age' (vol. 17), 'Goldwork of the Iron Age in Barbarian Europe' (vol. 18) and 'The Gilding of Lorenzo Ghiberti's Doors of Paradise' (vol. 19) have all contributed to a fuller appreciation of the use made of gold by our ancestors. By soliciting these articles and publishing them with a profusion of colour illustrations, Gold Bulletin has performed a great service to the world of learning. I for one look forward with relish to the next twenty years.

\section{References}

1 M.S. Banks and E.T. Hall, 'X-ray fluorescent analysis in Archaeometry: the Milliprobe', Archaeometry, 1963, 6, 31-36 
2 S.C. Hawkes, J.M. Merrick and D.M. Metcalf, 'X-ray fluorescent analyses of some Dark Age coins and jewellery', Archaeometry, 1966, 9, 98-138

3 D.M. Metcalf, J.M. Merrick and L.K. Hamblin, 'Studies in the Composition of Early Medieval Coins', Minerva Numismatic Handbooks, No. 3, Newcastle-upon-Tyne, 1968

4 P.D.C. Brown and F. Schweizer, 'X-ray fluorescent analysis of Anglo-Saxon jewellery', Archaeometry, $1973,15(2), 175-192$

5 R. Bruce-Mitford, 'The Sutton Hoo Ship-Burial' .Volume 3, (ed. A.C. Evans), British Museum, London, 1983 (especially ch.1)

6 J.P.C. Kent, 'Gold standards of the Merovingian Coinage, A.D. 580-700, in Methods of Chemical and Metallurgical Investigation of Ancient Coinage", (ed. by E.T. Hall and D.M. Metcalf), Royal Numismatic Society Special Publication, No. 8, London, 1972, pp 69-74

7 W.A. Oddy and M.J. Hughes, 'The specific gravity method for the analysis of gold coins', in Hall and Metcalf, op. cit., pp 75-87 and 96-107

8 R. Bruce-Mitford, 'The Sutton Hoo Ship-Burial', Volume 1, British Museum, London, 1975, (especially ch. 9)

9 M.J. Hughes and W.A. Oddy, 'A reappraisal of the specific gravity method for the analysis of gold alloys', Archaeometry, 1970, 12(1), 1-11

10 W.A. Oddy, 'The analysis of gold coins : a comparison of results obtained by non-destructive methods', Archaeometry, 1972, 14(1), 109-117

11 W.A. Oddy and S.M. Blackshaw, 'The accuracy of the specific gravity method for the analysis of gold alloys', Archaeometry, 1974, 16(1), 81-90

12 R.F. Coleman and A. Wilson, 'Activation analysis of Merovingian gold coins', in Hall and Metcalf, op. cit., pp 88-92

13 C. Morrisson et al., 'L'Or Monnayé 1: Purification et Altérations de Rome à Byzance', Cahiers ErnestBabelon, No. 2, Centre National de la Recherche Scientifique, Paris, 1985

14 D.M. Metcalf, 'Analyses of the metal contents of Medieval coins', in Hall and Metcalf, op. cit., pp 383434

15 W.A. Oddy, 'The debasement of provincial Byzantine gold coinage in the seventh and eighth centuries', a paper read to the Royal Numismatic Society, London, on 20 May 1975

16 For example: C. Morrisson, 'Numismatique et Histoire. L'or monnayé de Rome à Byzance: purification et altérations, Académie des Inscriptions et BellesLettres', Comptes Rendus, 1982, 203-223; and C. Morrisson et al., 'Nouvelles recherches sur l'histoire monétaire Byzantine: évolution comparée de la monnaie d'or à Constantinople et dans les provinces d'Afrique et de Sicile', Jahrbuch der Oesterreichischen Byzantinistik, 1983, 33, 267-286

17 S.C. Munro-Hay, 'The Coinage of Aksum, New Delhi and Glastonbury', 1984

18 S.C. Munro-Hay, 'The Chronology of Aksum, a Reappraisal of the History and Development of the Aksumite State from Numismatic and Archaeological
Evidence', Doctoral Thesis, University of London, 1978

19 S.C. Munro-Hay, W.A. Oddy and M.R. Cowell, 'The gold coinage of Aksum: new analyses and their significance for chronology', Metallurgy in Numismatics, 1988,2 , in the press

20 W.A. Oddy and V.E.G. Meyer, 'The analysis of the gold finds from Helgö and their relationships to other Early Medieval gold', in Excavations at Helg̈̈ X (ed. A. Lundström and H. Clarke), Stockholm, 1986, pp 153173

21 M.J. Hughes et al., "Report on the analysis of the gold of the Sutton Hoo jewellery and some comparative material', in R. Bruce-Mitford, The Sutton Hoo Ship Burial, vol. 2, British Museum, London, 1978, pp 618625

22 W.A. Oddy, 'The gold contents of Fatimid coins reconsidered', in Metallurgy in Numismatics, 1980, $\mathbf{1}$, 99-118, together with other papers cited in the bibliography

23 W.A. Oddy and S. La Niece, 'Byzantine gold coins and jewellery: a study of gold contents', Gold Bull., 1986, 19(1), 19-27

24 J.M. Ogden, 'Platinum group metal inclusions in ancient gold artifacts', J. Hist. Metall. Soc., 1977, 11, 53-72

25 N.D. Meeks and M.S. Tite, 'The analysis of platinumgroup element inclusions in gold antiquities', $J$. Archaeological Science, 1980, 7, 267-275

26 A. Hartmann, 'Prähistorische Goldfunde aus Europa', Studien zu den Anfängen der Metallurgie, Band 3), Berlin, 197?

27 A. Hartmann, 'Irish and British gold types and their West European counterparts', in The Origins of Metallurgy in Atlantic Europe (ed. M. Ryan), Dublin, 1978, pp 215-228

28 For example: P. Grierson and M. Blackburn, Medieval European Coinage 1 The Early Middle Ages (5thI0th Centuries), Cambridge, 1986; C. Johns and T. Potter, The Thetford Treasure. Roman Jewellery and Silver, British Museum, London, 1983

29 B. Arrhenius, Merovingian Garnet Jewellery, Stockholm, 1985

$30 \mathrm{~J}_{\mathrm{w}}$ Ogden, Jewellery of the Ancient World, London, 1982

31 W.A. Oddy, 'The production of gold wire in antiquity', Gold Bull., 1977, 10(3), 79-87

32 W.A. Oddy, 'The gilding of Roman silver plate', in press. (To be published in the proceedings of a conference on early Christian and Byzantine silver held in Paris in October 1983)

33 W.A. Oddy, 'Vergolden auf prähistorischen und klassischen Bronzen', in Archäologische Bronzen. antike Kunst, moderne Technik (ed. H. Born), Berlin, 1985, pp 64-71

34 L.B. Hunt, 'The early history of gold plating', Gold Bull., 1973, 6(1), 16-27

35 W. Bray, 'Gold-working in ancient America', Gold Bull., 1978, 11(4), 136-143

$36 \mathrm{H}$. Lechtman, 'A pre-Columbian technique for electrochemical replacement plating of gold and silver on copper objects', J. Met., 1979, 31(12), 154-160 